\title{
Ionic Channels in Mouse Astrocytes in Culture
}

\author{
Linda Nowak, ${ }^{1, a}$ Philippe Ascher, ${ }^{1}$ and Yoheved Berwald-Netter ${ }^{2}$ \\ 'Laboratoire de Neurobiologie, Ecole Normale Supérieure, Paris, and 'Laboratoire de Biochimie Cellulaire, Collège de \\ France, Paris, France
}

\begin{abstract}
We observed $\mathrm{Na}, \mathrm{K}$, and $\mathrm{Cl}$ voltage-dependent currents in a patch-clamp study of mouse brain astrocytes. In wholecell recordings, depolarizations activated inward currents that were identified as $\mathrm{Na}$ currents since they were blocked by TTX, although complete block required high concentrations $(>1 \mu \mathrm{M})$. The corresponding single-channel $\mathrm{Na}$ currents were observed in outside-out patches. The channels were opened by a depolarizing pulse applied from a holding potential identical to the resting potential $(-70$ to $-80 \mathrm{mV})$. Therefore, they may be considered functional $\mathrm{Na}$ channels. After addition of veratridine and an $\alpha$-scorpion toxin, the decay of $\mathrm{Na}$ currents in whole-cell recordings was slower than observed under control conditions. At the single-channel level, the channels appeared to open in bursts. Depolarization did not increase the duration of the bursts, but inside each burst, increased the time spent in the open state.

The $K$ currents observed in the whole-cell recording mode were separated into inactivating and noninactivating currents. The inactivating current resembled the $A$ current in its kinetics, its insensitivity to tetraethylammonium, and its sensitivity to 4-aminopyridine. At the single-channel level, at least 3 classes of $K$ channels were observed at steady depolarized potentials. They resembled the $K$ channels found in chromatfin cells by Marty and Neher (1985). Large conductance channels (385 pS) activated around $0 \mathrm{mV}$ were identified as $\mathrm{Cl}$ channels.
\end{abstract}

During the 10 years following the classical studies of Kuffler et al. (1966) that established that the resting potential in leech glial cells is very close to the $K$ equilibrium potential, a number of similar observations were made on other glial cells (reviewed in Orkand, 1977). Thus, at the end of the 1970s, it was commonly accepted that the ionic channels of the glial cell membrane were mostly, and possibly exclusively, $\mathrm{K}$ channels. In recent years, however, this notion has been challenged, largely due to the development of a series of specific markers of neuronal Na channels, including Na channel blockers, such as TTX and saxitoxin (STX), and Na channel "activators," such as veratridine, scorpion toxins, and sea anemone toxins (see Catterall,

Received Dec. 17, 1985; revised Apr. 11, 1986; accepted June 4, 1986.

This work was supported by the Universite Pierre et Marie Curie, the CNRS (UA 04-0295, UA 04-1115), the MRT (81E 1382), and INSERM (CRE 83-6003, 85-6001). L.N. was the recipient of a NSF-CNRS exchange fellowship. We thank Drs. A. Marty and A. Trautmann for help in computer programming and for stimulating discussions, and Dr. F. Couraud for the gift of scorpion toxin.

Correspondence should be addressed to Dr. P. Ascher, Laboratoire de Neurobiologie, Ecole Normale Supérieure, 46, rue d'Ulm, 75230 Paris Cedex 05, France.

"Present address: Department of Pharmacology, NYS College of Veterinary Medicine, Cornell University, Ithaca, NY, 14853.

Copyright (C) 1987 Society for Neuroscience $0270-6474 / 87 / 010101-09 \$ 02.00 / 0$
1980). When these compounds were applied to glial cells, it was found that a number of them showed substantial binding and could modulate $\mathrm{Na}$ permeability as demonstrated by isotopic $\mathrm{Na}$ flux measurements or by electrical potential changes (Barnola et al., 1973; Munson et al., 1979; Berwald-Netter et al., 1983, 1986; Reiser and Hamprecht, 1983; Reiser et al., 1983; Ritchie and Rang, 1983; Bowman et al., 1984; Y. BerwaldNetter, D. Beaudoin, E. Houzet, and F. Couraud, unpublished observations).

With the advent of the patch-clamp techniques (Hamill et al., 1981), a more direct characterization of ionic channels in glial cells became possible. The first studies, done on oligodendrocytes (Kettenmann et al., 1982, 1984) reported only voltage-insensitive $\mathrm{K}$ channels. However, when we applied the patch-clamp method to astrocytes treated with veratridine and scorpion toxin, we found evidence for the presence of $\mathrm{Na}$ channels, as well as of a number of other ionic channels (Nowak et al., 1983). The present paper represents a more detailed report of these observations, as well as some data obtained in the absence of toxins. These results are compared with those recently published on Schwann cells and astrocytes (Bevan et al., 1984, 1985a, b; Chiu et al., 1984; Gray et al., 1984; Bevan and Raff, 1985; Gray and Ritchie, 1985; Shrager et al., 1985; Quandt and MacVicar, 1986).

\section{Materials and Methods}

Cell culture. Cultures of mouse brain astrocytes were prepared essentially as described by Berwald-Netter et al. (1981). Cerebral hemispheres of newborn, random-bred Swiss mice were dissected into ice-cold PBS, and the meninges were carefully peeled off. The tissue was dissociated in to singlc cclls by sequential soaking in $\mathrm{Ca}, \mathrm{Mg}^{2+}$-free $\mathrm{PBS}$, brief treatment with Viokase (Gibco) diluted 1:20, and gentle trituration through a flame-polished Pasteur pipette. The cells were seeded onto $100 \mathrm{~mm}-$ diameter plastic tissue culture plates (Corning) at about $5 \times 10^{6}$ viable cells/plate in Dulbecco's modified Eagle's medium (DMEM, Gibco, H16) supplemented with glutamine, $0.3 \mathrm{mg} / \mathrm{ml}$; fungizone, $0.25 \mu \mathrm{g} / \mathrm{ml}$; penicillin, $100 \mathrm{U} / \mathrm{ml}$; streptomycin, $50 \mu \mathrm{g} / \mathrm{ml}$; and $5 \%$ fetal calf serum (Flow). The cells were kept at $37^{\circ} \mathrm{C}$ in water vapor-saturated atmosphere containing $5 \% \mathrm{CO}_{2}$. The culture medium was changed at $48 \mathrm{hr}$ and then every 4-5 d, until confluency was attained. Secondary cultures were prepared by dissociation of the primary cell monolayer with Viokase $(1: 20)$ and replating into $35-\mathrm{mm}$-diameter tissue culture plates (Nunc or Corning) at $2 \times 10^{5}$ cells/plate. Well-dispersed, nonconfluent cultures were maintained by including cytosine arabinoside $(1 \mu \mathrm{g} / \mathrm{ml})$ in the culture medium. Occasionally, primary or tertiary cultures were used, and in both cases we observed (in the whole-cell recording mode) inward currents similar to those described in Results. Astrocytes were identified by immunucy tochemical staining with antibodies to glial fibrillary acidic protein; they comprised about $95 \%$ of the cells in culture. They were not labeled by tetanus toxin and therefore correspond to the type I astrocytes as defined by Raff et al. (1983). Neither neurons nor oligodendrocytes were observed in multiple screenings of the cultures. The remaining cells $(5 \%)$ were flat, GFAP-negative cells, possibly of meningeal and/or endothelial origin. 
Figure 1. Whole-cell recordings. $A$, The left-hand records show results obtained when the main cation in the pipette solution was $\mathrm{K}^{+}$(see Materials and Methods). There is evidence of both a small inward current and a larger outward current activated by depolarizing pulses. Voltage jumps were applied from a holding potential of $-100 \mathrm{mV}$ to -60 , $-50,-40,-30$, and $-20 \mathrm{mV}$. $B$, The right-hand records are from a similar experiment done with $\mathrm{CsCl}$ substituted for $\mathrm{KCl}$ and show only an inward current. The holding potential was -100 $\mathrm{mV}$, and the jumps were made to -70 , $-60,-50$, and $-30 \mathrm{mV}$. Leak and capacitative currents were not subtracted. Records were sampled at $4 \mathrm{kHz}$ and filtered at $1 \mathrm{kHz}$.
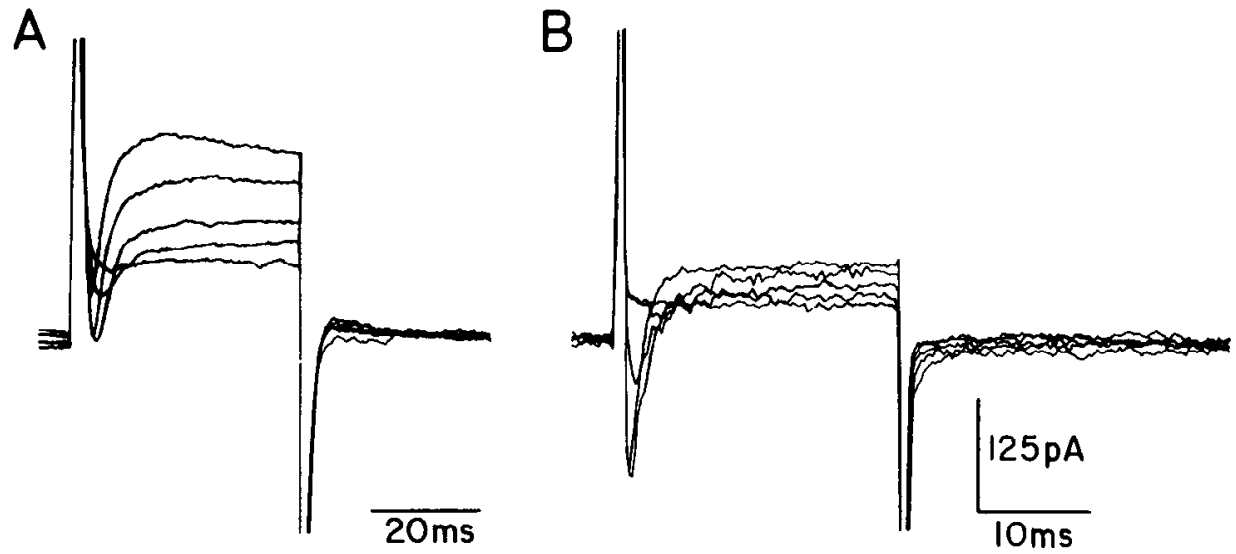

In most experiments, dibutyryl-cAMP at $0.25 \mathrm{mM}$ (Bowman et al., 1984) was added to the culture medium 6 or $24 \mathrm{hr}$ before the recording. This induced the cells to round up and facilitated contact with the patchclamp pipettes. Since such treatment might induce some of the currents observed, a few experiments were performed on cells not treated with dibutyryl-cAMP. In these experiments (in the whole-cell recording mode), we recorded both $\mathrm{Na}$ and $\mathrm{K}$ currents similar to those observed after treatment with dibutyryl-cAMP. We cannot exclude, however, that this treatment may have altered some properties of either the $\mathrm{Na}$ or the $\mathrm{K}$ channels.

Electrophysiological techniques. Pipettes were pulled from soft glass (Kimble) and coated with Sylgard, and their tips polished by heating. Pipette resistances were between 2 and $8 \mathrm{M} \Omega$ when they were filled with either a $\mathrm{K}$ solution containing (in mM/liter) $140 \mathrm{KCl}, 2 \mathrm{MgCl}_{2}, 5 \mathrm{EGTA}$ $\mathrm{K}, 0.5 \mathrm{CaCl}_{2}, 10$ HEPES-K, or a Cs- and Na-containing solution, in which $\mathrm{KCl}$ was replaced by $\mathrm{CsCl}$, and $\mathrm{NaCl}$ was added at a concentration of $4 \mathrm{~mm}$. The $\mathrm{pH}$ was titrated to 7.2.

The extracellular bath solution contained (in $\mathrm{mm} / \mathrm{liter}$ ) $140 \mathrm{NaCl}, 2$ $\mathrm{MgCl}_{2}, 2.8 \mathrm{KCl}, 1.0 \mathrm{CaCl}_{2}, 10$ HEPES-Na (pH 7.2) for the 2 major configurations uscd, wholc-ccll and outsidc-out patch rccordings (Hamill et al., 1981). In a few experiments, inside-out patches were used. The composition of the test solutions used in these cases is described in the text.

The currents were recorded with a List EPC-5 patch-clamp amplifier, and stored on magnetic tape (Racal). Analog data were filtered (see figure legends), digitized, and analyzed with the aid of a PDP 11-23.

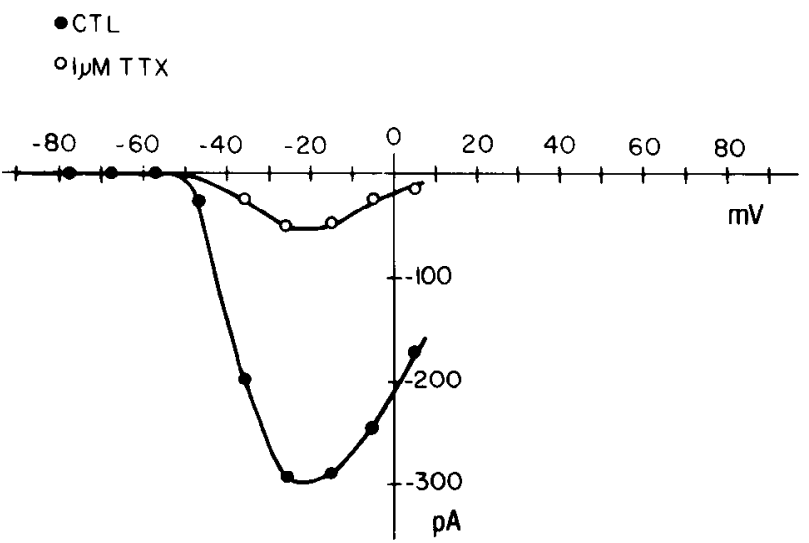

Figure 2. Effects of TTX on the whole-cell Na currents. The inward current was evaluated from records such as that of Figure $1 B$, after correction for a leak current calculated by linear extrapolation of the $I-$ $V$ relation between -60 and $-90 \mathrm{mV}$, in cells dialyzed with Cs. The holding potential was $-90 \mathrm{mV}$. Filled circles show the control $(C T L)$ current, and open circles represent the currents measured in the presence of $1 \mu \mathrm{M}$ TTX. Given the large size of the capacitive transient, the $\mathrm{Na}$ current is likely to have been underevaluated at potentials above -10 $\mathrm{mV}$.
Pharmacological agents. Toxin II from the scorpion Androctonus australis Hector (AaHII) (ScTx), a gift of F. Couraud, was prepared as described hy Miranda et al. (1970). It was added to the bath solution in conjunction with $0.1 \%$ BSA (Sigma). In most cases, $0.3 \mu \mathrm{M} \mathrm{ScTx}$ and $20 \mu \mathrm{M}$ veratridine were used. On a few occasions the veratridine concentration was 100 times lower.

The other drugs used were tetraethylammonium chloride (TEA; Carlo Erba), 4-aminopyridine (4-AP; British Drug Houses), and TTX (Sigma).

\section{Results}

\section{Sodium channels}

\section{Sodium currents in whole-cell recordings}

We restricted our analysis of whole-cell currents to relatively small and regularly shaped cells because large astrocytes, which are flat and irregular in shape, are particularly difficult to voltageclamp well. Despite this, the capacitive transients could rarely be eliminated by "subtraction" mcthods, and generally our records were not corrected. A few experiments were done using $\mathrm{K}$-containing pipettes, but in most cases $\mathrm{Cs}$-filled pipettes were used so that outward currents were blocked. The resting potential, measured immediately after entering the whole-cell recording mode, was $-74.3 \pm 15 \mathrm{mV}(n=25)$. The holding potential was usually set at -70 or $-80 \mathrm{mV}$, i.e., close to the resting potential.

In two thirds of the 27 cells tested, fast inward currents were observed as soon as the depolarizing pulse reached $-60 \mathrm{mV}$. The threshold of these inward currents was $20 \mathrm{mV}$ more negative than that of the major $\mathrm{K}$ currents (see below). Peak inward currents were measured near $-20 \mathrm{mV}$ and varied in size between 65 and 500 pA (Fig. 1).

These fast inward currents were identified as $\mathrm{Na}$ currents on the basis of their sensitivity to TTX, which produced a reversible blockade without altering the shape of the $I-V$ relation (Fig. 2). The concentration of TTX producing a $50 \%$ reduction of the inward current was estimated to be $400 \mathrm{nM}$ based upon inhibition measured in different concentrations of TTX. The inward current was unaffected by the addition of cobalt $(3 \mathrm{~mm})$ to the extracellular solutions, and it decreased when the extracellular $\mathrm{Na}$ concentration was reduced by substitution with choline. A dircct measurement of the reversal potential of the current was not obtained due to the apparent persistence, even in Cs-filled cells, of a small amount of fast outward current.

The whole-cell Na currents were then analyzed in the presence of 2 toxins known to reduce $\mathrm{Na}$ inactivation: $\alpha$-scorpion toxin $(\mathrm{ScTx})$ and veratridine. The 2 toxins were added (ScTx, $3 \times$ 


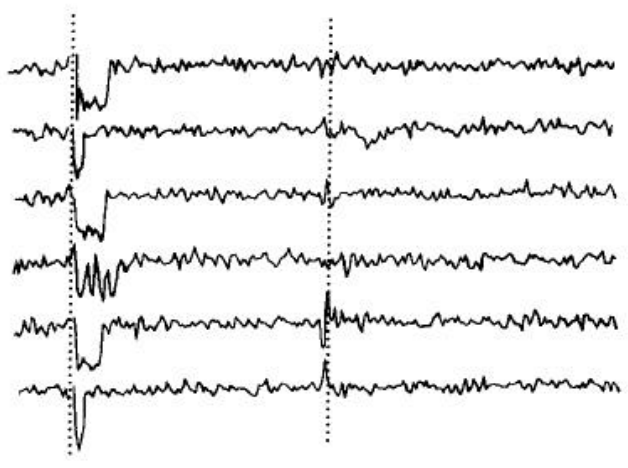

$10 \mathrm{~ms}$
B

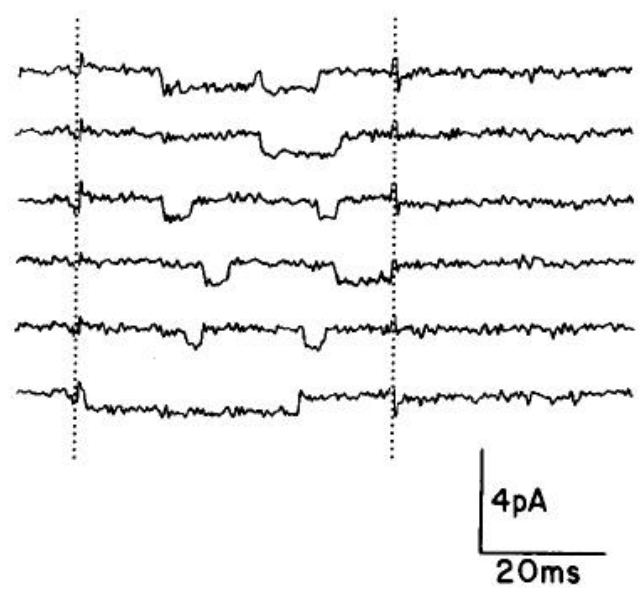

Figure 3. Sodium currents from outside-out patches. The pipette solution contained $\mathrm{CsCl}$ as the main electrolyte. The records in the $A$ column were obtained in control conditions; those of the $B$ column were obtained from a cell treated with veratridine $\left(2 \times 10^{-5} \mathrm{M}\right)$ and $\operatorname{ScTX}\left(6 \times 10^{-7} \mathrm{M}\right)$. The 6 records illustrated in $A$ and $B$ were chosen because they contained single channels, but in both cases they do not represent sequential records since they were separated by records that did not contain any openings. The holding potential was $-110 \mathrm{mV}$ in $A$ and $-70 \mathrm{mV}$ in $B$. The test potential during the voltage pulses (between the dotted lines) was $-15 \mathrm{mV}$ in both cases. The current calibration is common to both series of records. Data were sampled at $5 \mathrm{kHz}$ and filtered at $1 \mathrm{kHz}$. Leak and capacity transients were removed by subtracting records that did not contain channel openings.
$10^{-7} \mathrm{M}$; veratridine, $2 \times 10^{\mathrm{s}} \mathrm{M}$ ) to mimic the conditions under which they had been used previously in tracer flux experiments (Berwald-Netter et al., 1981) and electrophysiological studies (Bowman et al., 1984). The addition of the 2 toxins had little effect on the resting membrane potential, which was $-74.3 \pm$ $15 \mathrm{mV}(n=25)$ in control recordings and $-69.1 \pm 16 \mathrm{mV}(n=$ 26 ) in toxin-treated cells. Voltage-activated inward currents recorded in 3 toxin-treated cells had a range of activation and an $I-V$ curve similar to those in controls. The major difference was the longer duration of the inward current in the presence of the toxins. In both control and toxin-treated cells the decay of the current observed during depolarizing jumps was approximately exponential. The time constant of the exponential varied between 1 and $3 \mathrm{msec}$ in the controls and was increased to between 5 and $10 \mathrm{msec}$ in the toxin-treated cells. (The time constant of decay was more rapid for larger depolarizations in both conditions.) Thus, at the macroscopic level, the effect of the toxin appeared similar to that described for many peptide toxins in neurons and in other "excitable" cells (see Hille, 1984).

\section{Sodium channels in outside-out patches}

Single Na channels were observed in only 6 of the 69 outsideout patches studied, and only one of these patches was from an astrocyte that was not treated with the toxins. The small number of channel-containing patches observed in our experiments strongly suggests that the density of $\mathrm{Na}$ channels in astrocytes is lower than in neurons. (In parallel attempts on neurons in primary cultures, $\mathrm{Na}$ channels were found on nearly every outside-out patch.)

Records obtained from the "control" outside-out patch are shown in Figure 3. The channel opened at the beginning of the depolarizing pulse (to $-15 \mathrm{mV}$, from a holding potential of $-110 \mathrm{mV}$ ), closed, and did not reopen. The elementary current was $-1.4 \mathrm{pA}$ at $-15 \mathrm{mV}$.

In the presence of veratridine and ScTx, the picture changed; Figures 3-5 illustrate the 2 major effects of the toxins: (1) a prolongation of the mean open time, with a reopening of the channels during a continued depolarization, and (2) a shift of the activation curve.

The prolongation of the mean open time is illustrated in Figure 3 , in which a direct comparison is possible with records obtained on a non toxin-treated patch. Note that the open time on the 2 series of records can be directly compared, since the records correspond to channels opening at the same potential $(-15 \mathrm{mV})$. The latencies of the first openings cannot be directly compared, however, since the holding potential was much higher for the records on the left $(-110 \mathrm{mV})$ than for those on the right $(-70 \mathrm{mV})$. Clearly, there were successive openings during the
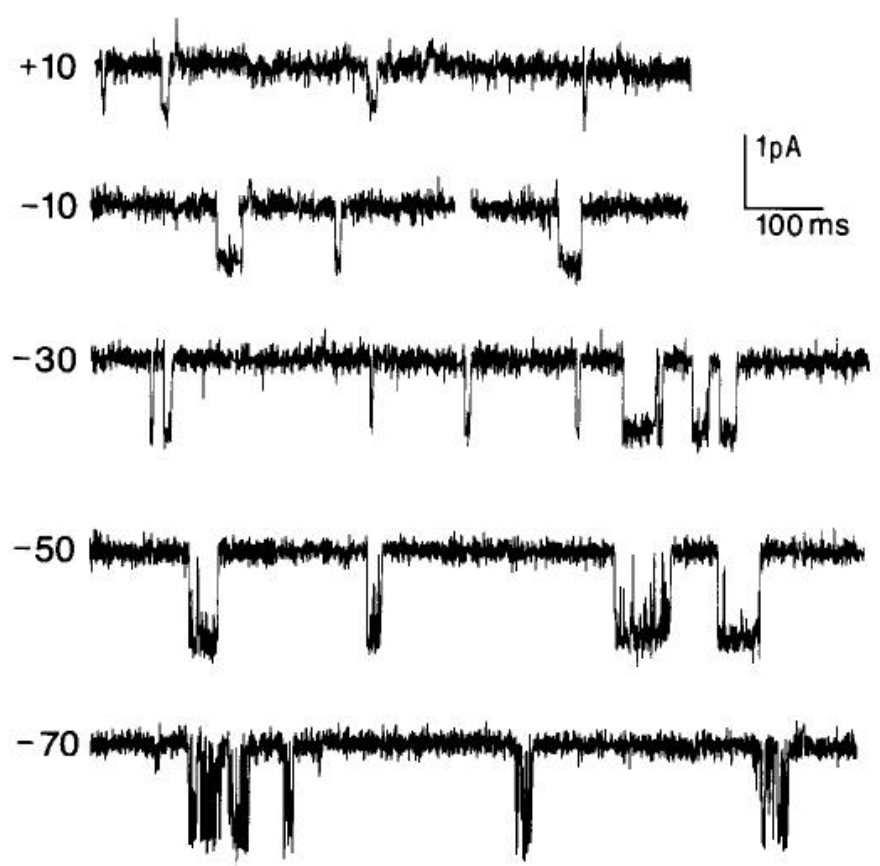

Figure 4. Sodium currents of an outside-out patch treated with ScTX $\left(3 \times 10^{7} \mathrm{M}\right)$. Selected records of openings observed at 5 distinct holding potentials from +10 to $-70 \mathrm{mV}$. The pipette solution was the Cs solution. The traces correspond to $3(+10,-10,-70)$ or $4(-30,-50)$ blocks of data, most of which were separated by "silent" blocks. The average frequency of the openings was therefore much lower than suggested by the figure. Note also that the events selected for the illustration were among the longest of those observed. Therefore, the average duration of the events is not accurately illustrated (see Fig. 5). The data were sampled at $10 \mathrm{kHz}$ and filtered at $2 \mathrm{kHz}$. 
Figure 5. Histogram of open times $\left(\tau_{0}\right)$, burst durations $\left(\tau_{\mathrm{b}}\right)$, and fast closed times $\left(\tau_{\mathrm{cf}}\right)$ obtained from records such as those illustrated in Figure 4. The data from the 2 potentials $(-30,-70 \mathrm{mV})$ show the approximate constancy of $\tau_{\mathrm{b}}$ as a function of membrane potential in contrast with the changes in $\tau_{0}$ and $\tau_{\mathrm{cr}}$. Additional measurements made at -50 $\mathrm{mV}$ confirmed the constancy of $\tau_{\mathrm{b}}$ and gave intermediate values for $\tau_{\mathrm{cf}}(0.5$ $\mathrm{msec})$ and $\tau_{0}(3.4 \mathrm{msec})$. Data were sampled at $10 \mathrm{kHz}$ and filtered at $1.2 \mathrm{kHz}$. Bursts durations were constructed by ignoring fast closures lasting less than $5 \mathrm{msec}$.

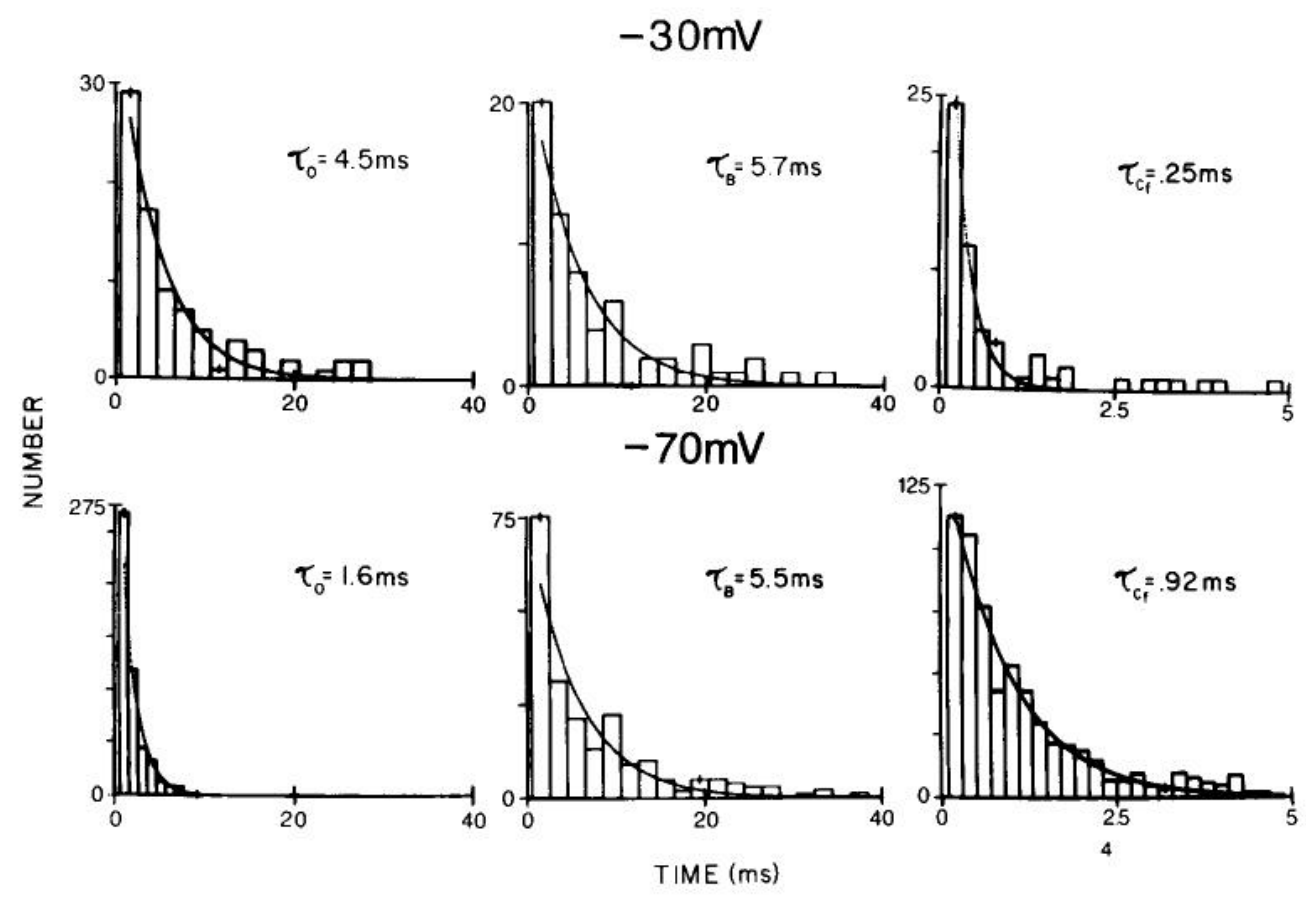

$100 \mathrm{msec}$ depolarizing pulses in toxin-treated patches. Since the number of channels present in the patch was not determined, it cannot be concluded that the same channel opened more than once. However, the fact that in a given patch activity could continue during many minutes, without our observing any second level of opening, strongly suggests that, in toxin-treated patches, the channels can reopen after having closed.

The range in which $\mathrm{Na}$ channels were seen to open was extended towards the hyperpolarized levels by addition of the toxins. In the experiment of Figure 4, a few channel openings were seen at $-90 \mathrm{mV}$, and many at $-70 \mathrm{mV}$. This suggests a shift of the activation curve towards more negative potential values.

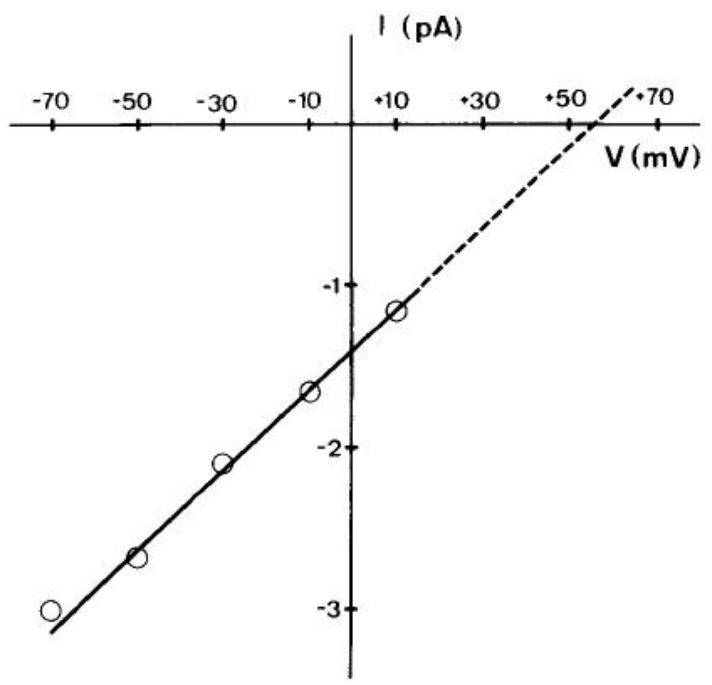

Figure 6. I- $V$ relation of the single-channel Na current. The data for this figure were from the same experiment as those of Figure 4, i.e., from an outside patch obtained from a cell treated with scorpion toxin. The reversal potential obtained by linear extrapolation is about +55 $\mathrm{mV}$. Mean values were obtained from amplitude histograms.

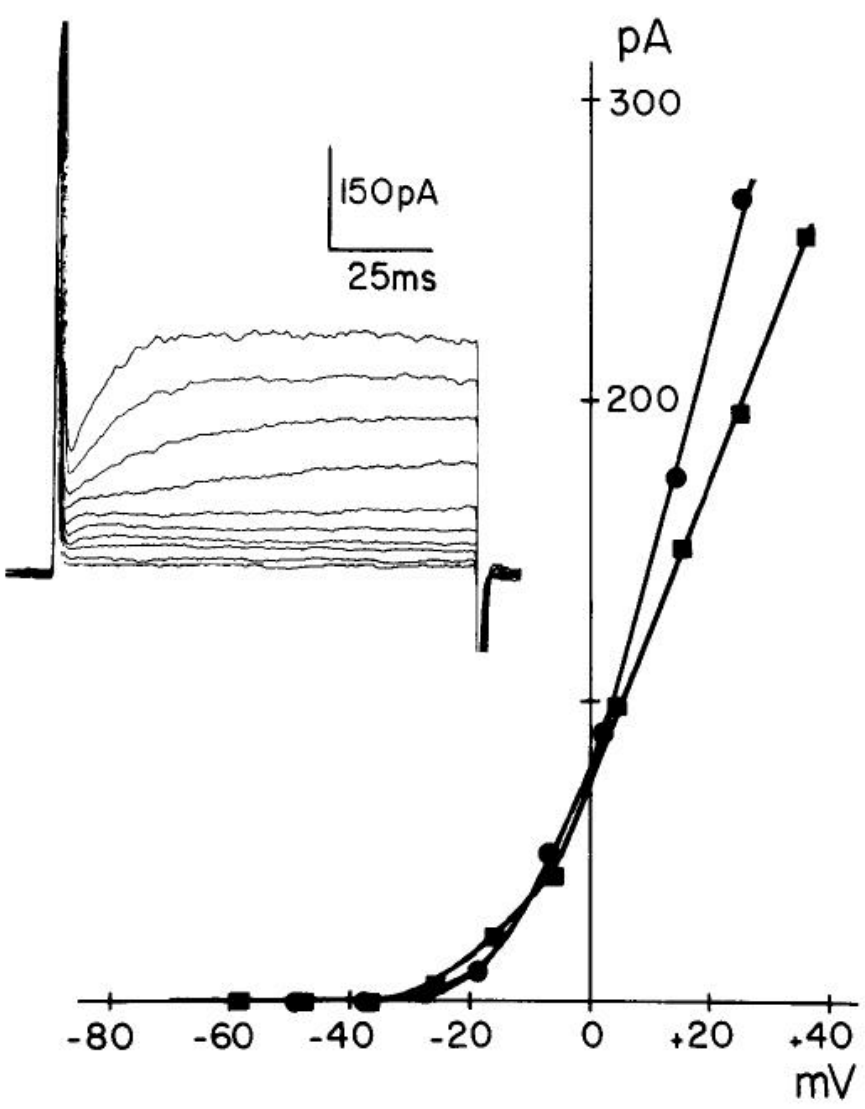

Figure 7. Whole-cell "noninactivating" K currents. Left, Voltage jumps of $+10 \mathrm{mV}$ increments were applied from a holding potential of -70 $\mathrm{mV}$. The pipette contained the "K-solution" (see Materials and Methods). Although no TTX was added to the extracellular solution in this experiment, there was no sign of an inward current. The 2 curves on the right correspond to data from 2 different cells: one (circles) in which the holding potential was $-60 \mathrm{mV}$ and which also had an inward current (as in Fig. 1), and the other (squares) at $-70 \mathrm{mV}$ which did not. 

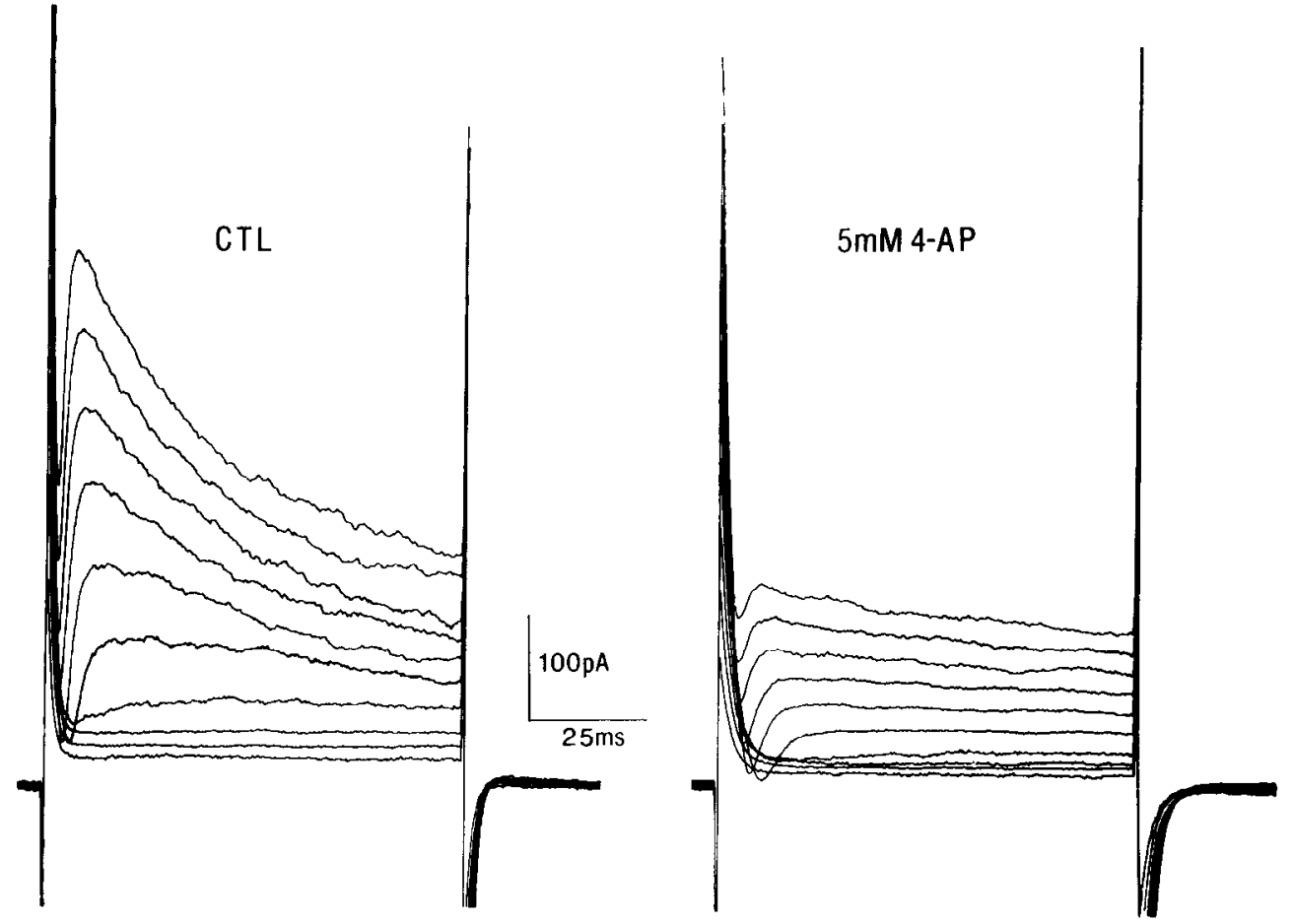

Figure 8. Sensitivity to 4-AP of the inactivating $\mathrm{K}$ current. Depolarizing pulses were applied from a holding potential of $-100 \mathrm{mV}$ to values from -80 to $+10 \mathrm{mV}$ (10 $\mathrm{mV}$ intervals). In the control $(C T L)$, pulses above $-60 \mathrm{mV}$ activated a transient outward current, as a small inward current. Addition of 4-AP ( 5 mM) markedly reduced the transient outward current.
The fact that channels opened repeatedly in the range from -70 to $+10 \mathrm{mV}$ allowed us to measure the duration of their opening. More precisely, 3 parameters were measured, since it appeared from the records in Figure 4 that the channels opened in bursts, particularly at more negative potentials. Characterization of these bursts was done by building histograms of the mean burst duration $\left(t_{\mathrm{b}}\right)$ and then, inside each burst, histograms of open times $\left(t_{\mathrm{o}}\right)$ and of "fast" closed times $\left(t_{\mathrm{c}}\right)$. The long closed times, indicative of the frequency of the bursts, were not analyzed in any detail.

The main result of this analysis (illustrated in Fig. 5) was that the mean burst time appeared to be independent of the membrane potential, and, in this experiment, was close to $5.6 \mathrm{msec}$. The internal structure of the burst, however, appeared to be voltage dependent: The mean duration of the open time increased, and the mean duration of the closed times decreased, when the patch was depolarized from -70 to $-30 \mathrm{mV}$.

The channels observed in the presence of veratridine and ScTx were blocked by TTX $(1 \mu \mathrm{M})$ and thus were considered to be $\mathrm{Na}$ channels. The mean slope conductance of these channels (obtained from the $I-V$ relation) was $14 \mathrm{pS}(12 \mathrm{pS}$ in Fig. 6). The mean extrapolated reversal potential was $+50 \mathrm{mV}(n=3)$ ( $+55 \mathrm{mV}$ in Fig. 6), while the Na equilibrium potential was at $+90 \mathrm{mV}$. It is probable that a more detailed analysis in the positive potential range will reveal an inward rectification and a higher reversal potential than deduced from linear extrapolation.

\section{Potassium channels}

In the whole-cell recording mode, outward currents activated by depolarization and attributable to $K$ conductances were observed in all 13 of the astrocytes analyzed with K-containing pipettes. These currents could be separated into 2 groups that differed in their inactivation during prolonged depolarization and in their potential of activation.
In 10 of the 13 cells tested, a "noninactivating" outward current was observed after applying depolarizing steps from a holding potential set between -50 and $-60 \mathrm{mV}$. The threshold of activation was around $-30 \mathrm{mV}$. No inactivation was detected during a pulse lasting $100 \mathrm{msec}$. The voltage dependence of this

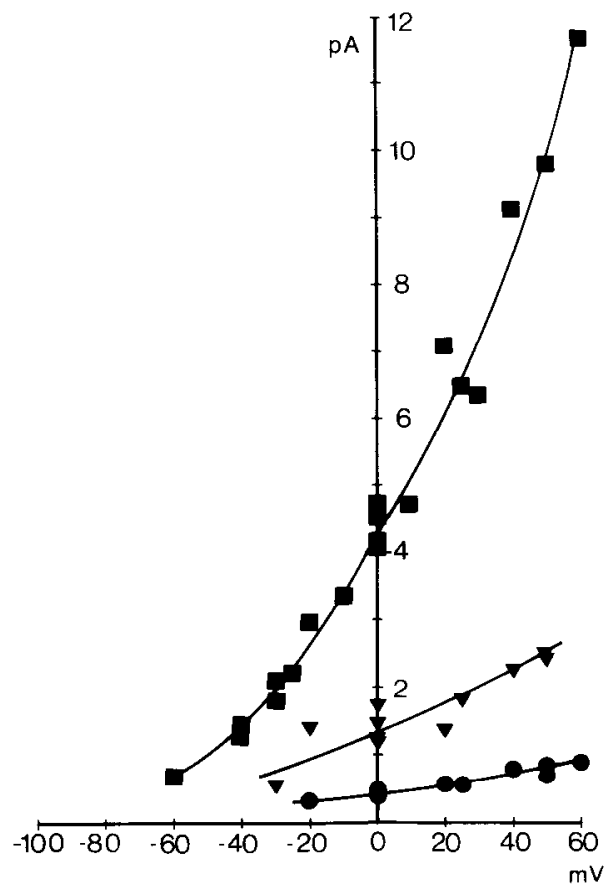

Figure 9. $I-V$ relation of single-channel $\mathrm{K}$ currents. $I-V$ relation of the 3 main types of single-channel currents observed in outside-out patches and attributed to $K$ channels. In all cases the pipette contained the $\mathrm{K}$ solution (see Materials and Methods). The slope conductances, calculated between 0 and $50 \mathrm{mV}$, were 110,20 , and $7 \mathrm{pS}$. 
Figure 10. Records from 2 outsideout patches held at $0 \mathrm{mV}$. In both cases the outward currents appear to constitute 2 classes. The mean values of the currents were 0.4 and $4.7 \mathrm{pA}(A)$ and 1.6 and $3.7 \mathrm{pA}(B)$.
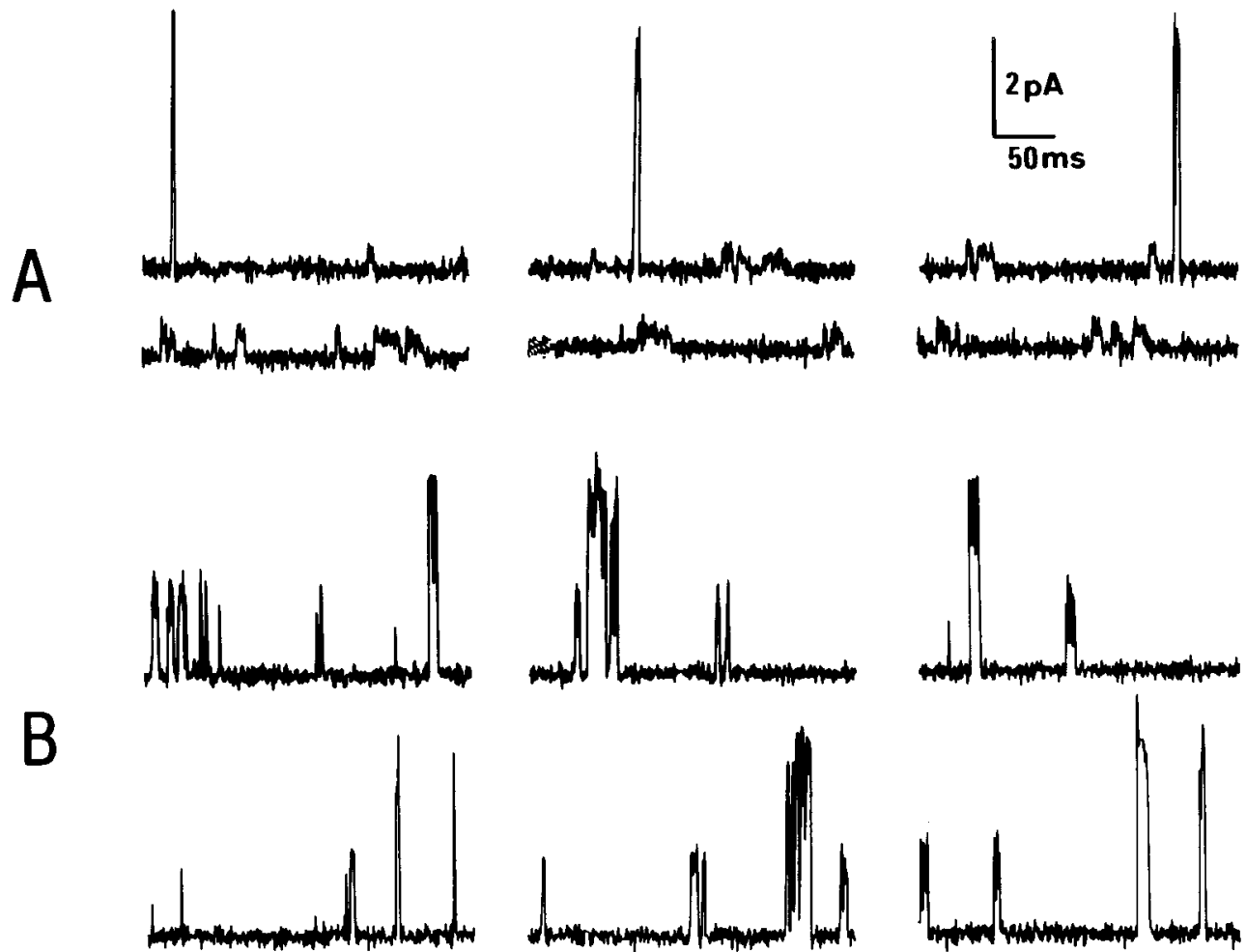

steady outward current, illustrated in Figure 7, is compatible with that of a $\mathrm{K}$ current. This identification was further supported by the fact that the outward current was reduced by a relatively low concentration of extracellular TEA $(5 \mathrm{mM})$.

In 4 of 7 cells, the use of a more negative holding potential $(-100$ to $-70 \mathrm{mV})$ revealed an inactivating outward current in addition to the noninactivating outward current described above. The activation of this current was faster than that of the noninactivating one. The inactivation was evaluated in 2 cells. The decay of the current could be described, in both cases, by a single exponential with a time constant of about $30 \mathrm{msec}$ that did not appear to be voltage dependent. The $I-V$ relation was compatible with the identification of the current as a $\mathrm{K}$ current. The size of the inactivating component of the total outward current was not noticeably affected by TEA $(5 \mathrm{~mm})$ but was strongly reduced by 4-AP ( $5 \mathrm{~mm}$ ) (Fig. 8 ).

In outside-out patches we observed a variety of outward single-channel currents that decreased with hyperpolarization but remained outward at negative potentials in conditions where $E_{\mathrm{C} 1}$ was equal to zero and where $E_{\mathrm{Na}}$ and $E_{\mathrm{Ca}}$ were positive. The currents were therefore identified as $\mathrm{K}$ currents. In many patches, there were so many simultaneous openings that no accurate $I-$ $V$ relation could be established. In 8 patches, however, there were sufficiently few channel openings to allow the separation of 3 families of currents and the construction of $I-V$ curves. Figures 9 and 10 illustrate some results from these patches. It was clear for the largest channel that the $I-V$ relation was not linear and had an outward rectification. This $I-V$ relation was compatible with a fit in which the inversion potential would be near the $\mathrm{K}$ equilibrium potential $(-100 \mathrm{mV})$. For the 2 smaller currents, the fit of the experimental points was less exact, but again clearly compatible with a $\mathrm{K}$ selectivity of the channels.

The presence of outward rectification in experiments such as those described above precludes the characterization of the channels by a unique conductance value. Therefore, the 3 channels were characterized by the amplitude of the elementary current recorded at $0 \mathrm{mV}$ (in pA): $4.3 \pm 0.2(6) ; 1.4 \pm 0.2$ (4), and $0.45 \perp 0.05$ (3) (mean $\pm \mathrm{SD}$, number of patches). The most frequently observed amplitude was the largest, which was present in 6 of the 8 patches. Most patches showed at least 2, and occasionally 3 , channel types. There appeared to be no preferred association between any 2 types of channels in a given patch.

The largest channel current resembled, by its size, the wellknown high-conductance, Ca-sensitive $\mathrm{K}$ channel described by many authors and referred to as "big K," or "BK," in Marty (1983). Inside-out patches were prepared in 6 experiments to test whether these astrocyte channels were sensitive to $\mathrm{Ca}$ and to evaluate their conductance. In most of these experiments the pipette contained a high-K $(140 \mathrm{~mm})$ solution, and the "internal" (bath) face of the patch was initially exposed to a low-K (2.8 $\mathrm{mm}$ ), Na-containing solution buffered at low pCa.

As expected, the $I-V$ relation in inside-out patches showed inward rectification. Replacing the bath solution with a high-K solution (identical to the pipette solution) transformed the $I-V$ relation into a linear one with the reversal potential at $0 \mathrm{mV}$. The conductance could now be defined unequivocally and had a value of $230 \mathrm{pS}$. This value is very close to that found for the "big K" channels observed in many other preparations (see Marty, 1983).

A further element of analogy was the fact that the channel showed a clear voltage dependence when the "internal" solution contained low Ca concentrations ( 5 mM EGTA, $0.5 \mathrm{~mm}$ Ca). When the internal solution contained $1 \mathrm{mM} \mathrm{Ca}$ (no EGTA), the voltage dependence disappeared, consistent with the observations of Barrett et al. (1982).

On the whole, the observations reported above consolidated 
the identification of the large $\mathrm{K}$ channel as a Ca-sensitive "BK" channel. However, the astrocyte channel appeared to be less sensitive to various pharmacological agents than the corresponding channels described in other systems. Externally applied TEA (10 mM) only reduced the current amplitude by $30 \%$ in an outside-out patch held at $0 \mathrm{mV}$. Its main effect was to reduce the channel opening frequency markedly. Similar small effects were seen with external applications of high concentrations of 4-AP $(40 \mathrm{mM})$, while quinine $(200 \mu \mathrm{M})$ reduced the current amplitude by $20 \%$ without any apparent effect on the frequency of the openings.

TEA (20 mM), Ba (10 mM), Cs (140 mM), and 4-AP (20 mm) were also applied on the "internal" surface of inside-out patches. The first 3 compounds had a clear blocking effect, whereas no effect was observed with internal 4-AP.

In a few experiments made on outside-out patches, the effect of substituting choline for $\mathrm{Na}$ in the extracellular solution was examined. Choline has been used as the major cation in a number of Na flux experiments in glial cells (e.g., Reiser and Hamprecht, 1983; Berwald-Netter et al., 1986; Y. Berwald-Netter, D. Beaudoin, E. Houzet, and F. Couraud, unpublished observations), and we were concerned about the possibility that such cells were depolarized by a K-blocking effect of choline (Frankenhaeuser, 1962). Indeed, substitution of choline for $\mathrm{Na}$ reduced the large $\mathrm{K}$ single-channel currents by about $60 \%$ at $0 \mathrm{mV}$. A similar effect was observed on the small $\mathrm{K}$ current measuring $1.4 \mathrm{pA}$ at $0 \mathrm{mV}$ in control saline.

\section{Chloride channels}

Two types of single-channel currents that we consider likely to be $\mathrm{Cl}$ currents were observed in outside-out patches.

Large conductance channels, very similar to those first described by Blatz and Magleby (1983) on muscle cells, and since found by Gray et al. (1984) and by Bevan et al. (1985b) on Schwann cells and astrocytes, were observed in 5 of 70 outsideout patches tested. The channels were mostly opened between -15 and $+30 \mathrm{mV}$. Above +30 and below $-40 \mathrm{mV}$ they closed rapidly. The conductance, measured in 4 patches, was $385 \pm$ $27 \mathrm{pS}$.

The reversal potential in symmetrical $\mathrm{Cl}$ was $+3.0 \pm 2.6 \mathrm{mV}$ (with internal $\mathrm{Cs}$, external $\mathrm{Na}$ ). The shifts observed when diluting the external solution with distilled water or substituting isethionate for $\mathrm{Cl}$ (Nowak et al., 1983) were similar to those reported by Gray et al. (1984) and indicate that the channel is anionic but with a finite cationic permeability and that it has a substantial permeability to isethionate.

In addition to these large conductance channels, small conductance channels, opened by hyperpolarization, were observed in a few outside-out patches. Records from such a channel clearly showed that the probability of opening increased when the patch was hyperpolarized from -40 to $-100 \mathrm{mV}$. The singlechannel conductance was close to $5 \mathrm{pS}$, but the channels also exhibited a half-conductance substate. The extrapolated reversal potential was near $0 \mathrm{mV}$ in the "symmetrical Cl" solution (internal Cs, external $\mathrm{Na}$ ). The selectivity of this channel was not analyzed in any detail. Our proposal for this being a $\mathrm{Cl}$ channel is based on the striking similarity it bears to the anionic channels described by Miller and his collaborators (see Miller and White, 1984) and more recently by Chesnoy-Marchais and Evans (1985). In both these cases the channels were activated by hyperpolarization, had a relatively low conductance, and were frequently observed in a "half-conductance" substate.

\section{Discussion}

Our observations confirm and extend the evidence for the existence of a surprising variety of ionic channels in astrocytes and, in particular, of voltage-activated $\mathrm{Na}$ and $\mathrm{K}$ channels. As discussed below, none of these channels appears specific to glial cells.

\section{Sodium channels}

In their basic properties, the astrocyte $\mathrm{Na}$ channels appeared to be indistinguishable from neuronal channels. The only clear difference appears to be their relative insensitivity to TTX.

The TTX sensitivity of the astrocytes Na current appears lower than that reported for neuronal $\mathrm{Na}$ channels. We have calculated that $400 \mathrm{nM}$ TTX was required to block half the Na current. This estimate agrees well with that obtained by Bevan et al. (1985), $520 \mathrm{~nm}$, under similar conditions, as well as with the value obtained by Berwald-Netter et al. (1985) from $\mathrm{Na}$ flux assays; it contrasts with the high affinity revealed by STX binding experiments in astrocytes (2 nM, Bevan et al., 1985; 1.25 nM, Berwald-Netter et al., 1986; Y. Berwald-Netter, D. Beaudoin, E. Houzet, and F. Couraud, unpublished observations). As discussed by Bevan et al. (1985), this strongly suggests the presence of 2 types of binding sites having high and low affinity for TTX or STX. It remains to be established whether the highaffinity binding sites are coupled to functional $\mathrm{Na}$ channels and if they are present on the same astrocytes as those possessing the low-affinity sites. Such a situation has been observed in other cells (e.g., Pappone, 1980; Frelin et al., 1983; Sherman et al., 1983; Gonoi et al., 1985). It could explain the observations of Bowman et al. (1984) that the "regenerative depolarizations" stimulated by ScTx and veratridine in astrocytes were blocked by as little as $10-16 \mathrm{~nm}$ TTX.

\section{Effects of veratridine and scorpion toxin}

Our observations in the whole-cell mode, as well as in outsideout patches, suggest that the effects of veratridine and scorpion toxins on astrocytes do not differ from those described in neurons, i.e., that the combined effects of the 2 drugs lead to a shift of the activation curve towards more negative potentials, combined with a reduced inactivation. As a result, Na channels may open repeatedly even at membrane potentials close to resting potential. This will lead to a substantial $\mathrm{Na}$ influx, and eventually to some regenerative depolarizations (Munson et al., 1979; Reiser et al., 1983; Berwald-Netter et al., 1984; Bowman et al., 1984). It does not appear necessary to assume that the toxins open "silent channels," if by this term one means channels that are normally unable to open during a depolarization. To explain the effect of the toxins, it is sufficient to assume that they allow $\mathrm{Na}$ channels to open longer, and at more negative potentials, than they do normally.

At the single-channel level, the Na channels in toxin-treated patches appear to open in bursts. The duration of these bursts appears, in a first approximation, to be voltage independent. It is tempting to try to correlate these observations to those of Aldrich et al. (1983), who observed that the mean open time of $\mathrm{Na}$ channels in neuroblastoma (N1E 115) cells is voltage independent and is close to $0.5 \mathrm{msec}$ at room temperature (see also Shrager et al., 1985; Vandenberg and Horn, 1984). If one assumes, as these authors did, that channel closing results mostly from the transition from the open state to the inactivated state, the mean open time is essentially the reciprocal of the inacti- 
vation rate constant. The fact that the mean open time is voltage independent agrees with the model proposed by Armstrong and Bezanilla (1977) and Armstrong and Gilly (1979), in which the (microscopic) inactivation rate is voltage independent. The voltage dependence of the whole-cell current decay ("macroscopic" inactivation rate) would then reflect the voltage dependence of activation rather than inactivation.

If we accept such a scheme, a simple explanation of our observations is that, after the action of the toxins, the rate of inactivation is reduced, producing a prolongation of the open time. Assuming that the mean open time in control conditions is in the same range as that reported by Aldrich et al. (1983), i.e., $0.5 \mathrm{msec}$, or by Shrager et al. (1985), i.e., $0.3 \mathrm{msec}$, the value of $5.5 \mathrm{msec}$ observed in the presence of scorpion toxin (Fig. 5) would indicate that, in this experiment, the toxins had slowed inactivation by a factor of about 10 .

A more complex model is required if the bursting observed at negative potentials (Fig. 5) is to be interpreted also. The fact that the burst duration appears to be voltage independent, while the mean open time during each burst increased with depolarization between -70 and $-30 \mathrm{mV}$ is consistent with the model proposed by Armstrong and Gilly (1979). This model assumes that the open state $\left(X_{1}\right)$ is reached after a succession of voltage dependent transitions between closed states $\left(X_{6}, X_{5}, \ldots X_{2}\right)$, and that there are 2 "inactivated" states $\left(X_{2} Z\right.$ and $\left.X_{1} Z\right)$ which can be reached either from the last closed state $\left(X_{2}\right)$ or from the open statc $\left(X_{1}\right)$ by voltage independent transitions. In normal conditions, the channel does not oscillate between $X_{2}$ and $X_{1}$ because the transition between these 2 states is substantially slower than inactivation. If, however, the toxins markedly slowed the rate of inactivation, it is conceivable that bursts corresponding to repeated transitions between $X_{2}$ and $X_{1}$ would be detected. The constancy of the burst duration with potential would then reflect the fact that the inactivation rate is voltage independent. The voltage dependence of the open time inside the burst would reflect the fact that depolarization favors the open state $\left(X_{1}\right)$ over the closed state $\left(X_{2}\right)$.

Finally, an additional effect - a shift of the activation curveis required to explain the finding that channels open at very negative potentials in toxin treated patches.

\section{Density of the sodium channels in astrocytes}

Following the early indications that $\mathrm{Na}$ channels are present in some "inexcitable" cells, there have been various proposals to reconcile these observations with the absence of an action potential. Romey et al. (1979) proposed that, in the C9 neuroblastoma clone, which lacks action potentials, inactivation was much faster than activation and did not allow the development of a substantial Na current. Shrager et al. (1985) and Bevan et al. (1985) found that, in rabbit Schwann cells possessing a high number of $\mathrm{Na}$ channels, the low value of the resting potential (around $-40 \mathrm{mV}$ ) probably prevents activation in normal conditions.

These 2 types of explanations do not apply in the case of the astrocytes that we have studied. The resting potential of the astrocytes was close to $-70 \mathrm{mV}$, at which potential the $\mathrm{Na}$ channels must be available for activation (see also Bevan et al., 1985). Thus, the Na channels that we have studied appear to be functional under our experimental conditions. A way to reconcile the existence of functional $\mathrm{Na}$ channels and inexcitability is to posit a low density of $\mathrm{Na}$ channels or, more generally, a low ratio of $\mathrm{Na}$ to $\mathrm{K}$ channels. This seems to us the more likely hypothesis.

It is supported by the results of experiments of Berwald-Netter et al. (1986; Y. Berwald-Netter, D. Bcaudoin, E. Houzet, and F. Couraud, unpublished observations) who reported that, in the same preparations that we used in our experiments, ScTx binding was $7 \mathrm{fmol} / 10^{6}$ cells and tritiated saxitoxin binding was $31 \mathrm{fmol} / 10^{6}$ cells $(121 \mathrm{fmol} / \mathrm{mg}$ protein). A similar value for saxitoxin binding ( $150 \mathrm{fmol} / \mathrm{mg}$ protein) was reported by Bevan et al. (1985). These values are low compared with the data on neurons (Ritchie and Rogart, 1977; D. Beaudoin, F. Couraud, E. Houzet, and Y. Berwald-Netter, unpublished observations).

\section{The potassium currents}

Our observations in the whole-cell recording mode generally agree with those of Bevan and Raff (1985) in indicating the presence of at least 2 classes of voltage dependent $K$ currents: a noninactivating $K$ current and a rapidly inactivating $K$ current. In addition, we have shown that the noninactivating current is sensitive to TEA, while the inactivating one is sensitive to $4-\Lambda \mathrm{P}$ ( $5 \mathrm{~mm}$ ). This suggests that the inactivating $\mathrm{K}$ current, like that described by Newman (1985) in retinal glial cells, may be an "A" current (see Adams et al., 1980).

The single-channel data were obtained only at steady-state potentials, and therefore do not allow a further characterization of the inactivating current. On the other hand, they suggest that the noninactivating $K$ current may be heterogeneous and involve several different $K$ channels. The best characterized of these channels resembles those labeled "BK" ("big K") by Marty (1983), which are activated by internal $\mathrm{Ca}$ as well as by membrane depolarization. The size of the single-channel $\mathrm{K}$ current recorded both in inside-out and outside-out configurations from astrocytes agrees with this identification. So does the sensitivity to $[\mathrm{Ca}]_{\mathrm{i}}$ observed in the inside-out configuration. The only property of the large $\mathrm{K}$ channel that does not correspond to that described by Marty, and others (see Marty, 1983), is the relatively low sensitivity to TEA. Concentrations of 5-10 mM were required to produce a blockade of the channel in outside-out patches, whereas concentrations 10 times lower were effective in other systems. However, this channel is very likely to contribute to the noninactivating voltage-activated outward current, since it does have some TEA sensitivity and its frequency of opening increases with depolarization.

The records obtained in the outside-out configuration indicate further that, in addition to the channel that we shall tentatively label "BK," there were at least 2 other, smaller, K channels. The size of the currents recorded at $0 \mathrm{mV}$ suggests an analogy with the $2 \mathrm{~K}$ channels recently described by Marty and Neher (1985) in chromaffin cells, and labeled FK and SK. One of these channels may correspond to the $18 \mathrm{pS}$ channel described by Shrager et al. (1985) in rabbit Schwann cells and to the $25 \mathrm{pS}$ (Ca activated) channel described by Quandt and MacVicar (1986) in astrocytes.

\section{References}

Adams, D. J., S. J. Smith, and S. H. Thompson (1980) Ionic currents in molluscan soma. Annu. Rev. Neurosci. 3: 141-167.

Aldrich, R. W., D. P. Corey, and C. F. Stevens (1983) A reinterpretation of mammalian sodium channel gating based on single channel recording. Nature 306: 436-441.

Armstrong, C. M., and F. Bezanilla (1977) Inactivation of the Na 
channel. II. Gating current experiments. J. Gen. Physiol. 70: 567590.

Armstrong, C. M., and W. F. Gilly (1979) Fast and slow steps in activation of sodium channels. J. Gen. Physiol. 74: 691-711.

Barnola, F. V., R. Villegas, and G. Camejo (1973) Tetrodotoxin receptors in plasma membranes associated from lobster nerve fibers. Biochem. Biophys. Acta 298: 84-94.

Barrett, J. N., K. L. Magleby, and B. S. Pallotta (1982) Properties of single calcium-activated potassium channels in cultured rat muscle. J. Physiol. (Lond.) 331: 211-230.

Berwald-Netter, Y., D. Beaudoin, and F. Couraud (1983) Contribution to the characterisation of astrocyte membrane properties. J. Neurochem. (Suppl.) 41:53.

Berwald-Netter, Y., N. Martin-Moutot, A. Koulakoff, and F. Couraud (1981) $\mathrm{Na}^{+}$-channel-associated scorpion toxin receptor sites as probes for neuronal evolution in vivo and in vitro. Proc. Natl. Acad. Sci. USA 78: $1245-1249$.

Berwald-Netter, Y., A. Koulakoff, F. Couraud, L. Nowak, and P. Ascher (1986) Ionic Channels in Glial Cells, S. Fedoroff and A. Vernadakis, eds., Academic, New York (in press).

Bevan, S., and M. Raff (1985) Voltage-dependent potassium currents in cultured astrocytes. Nature 315: 229-232.

Bevan, S., P. T. A. Gray, and J. M. Ritchie (1984) A calcium activated cation-selective channel in rat cultured Schwann cells. Proc. R. Soc. London [Biol.] 222: 349-355.

Bevan, S., S. Y. Chiu, P. T. A. Gray, and J. M. Ritchie (1985a) Sodium channels in rat cultured astrocytes. J. Physiol. (Lond.) 361 : 18P.

Bevan, S., S. Y. Chiu, P. T. A. Gray, and J. M. Ritchie (1985b) The presence of voltage gated sodium, potassium and chloride channels in rat cultured astrocytes. Proc. R. Soc. London [Biol.] 225: 299-313.

Blatz, A. L., and K. L. Magleby (1983) Single voltage-dependent chloride-selective channels of large conductance in cultured rat muscle. Biophys. J. 43: 237-241.

Bowman, C. L., H. K. Kimelberg, M. V. Frangakis, Y. Berwald-Netter, and C. Edward (1984) Astrocytes in primary culture have chemically activated sodium channels. J. Neurosci. 4: 1527-1534.

Catterall, W. A. (1980) Neurotoxins that act on voltage-sensitive sodium channels in excitable membranes. Annu. Rev. Pharmacol. Toxicol. 20: 15-43.

Chesnoy-Marchais, D., and M. Evans (1985) Two types of chloride channels in outside-out patches from Aplysia neurones. J. Physiol. (Lond.) 357: 64P

Chiu, S. Y., P. Shrager, and J. M. Ritchie (1984) Neuronal-type $\mathrm{Na}^{+}$ and $\mathrm{K}^{+}$channels in rabbit cultured Schwann cells. Nature 311: 156157.

Frankenhaeuser, B. (1962) Potassium permeability in myelinated nerve fibres of Xenopus laevis. J. Physiol. (Lond.) 160:54-61.

Frelin, C., P. Vigne, and M. Lazdunski (1983) $\mathrm{Na}^{+}$channels with high and low affinity tetrodotoxin binding sites in the mammalian skeletal muscle cell. J. Biol. Chem. 258: 7256-7259.

Gonoi, T., S. J. Sherman, and W. A. Catterall (1985) Voltage clamp analysis of tetrodotoxin-sensitive and insensitive sodium channels in rat muscle cells developing in vitro. J. Neurosci. 5: 2559-2564.

Gray, P. T. A., and J. M. Ritchie (1985) Ion channels in Schwann and glial cells. Trends Neurosci. 8: 411-415.

Gray, P. T. A., S. Bevan, and J. M. Ritchie (1984) High conductance anion-selective channels in rat cultured Schwann cells. Proc. R. Soc. London [Biol.] 221: 395-409.

Hamill, O. P., A. Marty, E. Neher, B. Sakmann, and F. Sigworth (1981) Improved patch-clamp techniques for high-resolution current recording from cells and cell-free membrane patches. Pfluegers Arch. 391: $85-100$

Hille, B. (1984) Ionic Channels of Excitable Membranes, Sinauer, Sunderland.

Kettenmann, H., R. K. Orkand, and H. D. Lux (1984) Some properties of single potassium channels in cultured oligodendrocytes. Pfluegers Arch. 400: 215-221.

Kettenmann, H., R. K. Orkand, H. D. Lux, and M. Schachner (1982) Single potassium channel currents in cultured mouse oligodendrocytes. Neurosci. Lett. 32: 41-46.

Kuffler, S. W., J. G. Nicholls, and R. K. Orkand (1966) Physiological properties of glial cells in the central nervous system of amphibian. J. Neurophysiol. 29: 768-787.

Marty, A. (1983) $\mathrm{Ca}^{2+}$ dependent $\mathrm{K}^{+}$channels with large unitary conductance. Trends Neurosci. 6: 262-265.

Marty, A., and E. Neher (1985) Potassium channels in bovine adrenal chromaffin cells. J. Physiol. (Lond.) 367: 117-141.

Miller, C., and M. M. White (1984) Dimeric structure of single chloride channels from Torpedo electroplax. Proc. Natl. Acad. Sci. USA 81: 2772-2775.

Miranda, F., C. Kupeyan, C. Rochat, and S. Lissitsky (1970) Purification of animal neurotoxins: Isolation and characterization of eleven neurotoxins from the venoms of Androctonus australis Hector, Buthus occitanus tunetanus and Leiurus quinquestriatus quinquestriatus. Eur. J. Biochem. 16: 514-523.

Munson, R., B. Westermark, and L. Glaser (1979) Tetrodotoxin-sensitive sodium channels in normal human fibroblasts and normal human glia-like cells. Proc. Natl. Acad. Sci. USA 76: 6425-6429.

Newman, E. A. (1985) Voltage-dependent calcium and potassium channels in retinal glial cells. Nature 317: 809-811.

Nowak, L., P. Ascher, Y. Berwald-Netter, and F. Couraud (1983) Single channel currents of cultured mammalian astrocytes studied using excised membrane patches. Neurosci. Lett. 14: S264.

Orkand, R. K. (1977) Glial cells. In Handbook of Physiology, The Nervous System, Vol. 1, E. R. Kandcl, cd., pp. 855-875, American Physiological Society, Bethesda, MD.

Pappone, P. A. (1980) Voltage-clamp experiments in normal and denervated mammalian skeletal muscle fibres. J. Physiol. (Lond.) 306: 377-410.

Quandt, F. N., and B. A. MacVicar (1986) Calcium activated potassium channels in cultured astrocytes. Neuroscience 19: 29-41.

Raff, M. C., E. R. Abney, J. Cohen, R. Lindsay, and M. Noble (1983) Two types of astrocytes in cultures of developing rat white matter: Differences in morphology, surface gangliosides and growth characteristics. J. Neurosci. 3: 1289-1300.

Reiser, G., and B. Hamprecht (1983) Sodium-channels in non-excitable glioma cells, shown by influence of veratridine, scorpion toxin and tetrodotoxin on membrane potential and on ion transport. Pfluegers Arch. 397: 260-264.

Reiser, G., F. Löffler, and B. Hamprecht (1983) Tetrodotoxin-sensitive ion channels characterized in glial and neuronal cells from rat brain. Brain Res. 261: 335-340.

Ritchie, J. M., and H. P. Rang (1983) Extra neuronal saxitoxin binding sites in rabbit myelinated nerve. Proc. Natl. Acad. Sci. USA 80:28032807.

Ritchie, J. M., and R. B. Rogart (1977) The binding of saxitoxin and tetrodotoxin to excitable tissue. Rev. Physiol. Biochem. Pharmacol. 79: $1-50$.

Romey, G., Y. Jacques, H. Schweitz, M. Fosset, and M. Lazdunski (1979) The sodium channel in non-impulsive cells-interaction with specific neurotoxins. Biochim. Biophys. Acta 556: 344-353.

Sherman, S. J., J. C. Lawrence, D. J. Messner, K. Jacoby, and W. A. Catterall (1983) Tetrodotoxin-sensitive sodium channcls in rat muscle cells developing in vitro. J. Biol. Chem. 258: 2488-2495.

Shrager, P., S. Y. Chiu, and J. M. Ritchie (1985) Voltage dependent sodium and potassium channels in mammalian cultured Schwann cells. Proc. Natl. Acad. Sci. USA 82: 948-952.

Vandenberg, C. A., and R. Horn (1984) Inactivation viewed through single sodium channels. J. Gen. Physiol. 84: 535-564. 